\title{
SYNTHESIS, SPECTROSCOPIC, AND BIOLOGICAL ACTIVITY STUDIES OF THE NI(II) COMPLEXES OF TRIDENTATE SCHIFF BASES
}

\author{
Ganesh More $^{1}$, Sakina Bootwala ${ }^{1}$, Swamini Patade ${ }^{2}$, Darshana Raut ${ }^{2}$ \\ and K. Aruna ${ }^{2}$ \\ ${ }^{1}$ Department of Chemistry, ${ }^{2}$ Department of Microbiology, Wilson College, \\ Mumbai, India-400007. \\ *E-mail: szbootwala@gmail.com
}

\begin{abstract}
$\mathrm{Ni}(\mathrm{II})$ complexes of the general formula $[\mathrm{Ni}(\mathrm{L}) \mathrm{Cl}]$ where $\mathrm{L}=$ Schiff base ligand, were synthesized from series of tridentate Schiff bases. The prepared compounds were characterized by different spectral analysis (FTIR and UVvisible) and various physicochemical methods (elemental analysis, magnetic susceptibility and molar conductance). One selected complex was subjected to thermogravimetric and X-ray diffraction analysis. The spectral data revealed coordination of Schiff base ligand through ester carbonyl, azomethine nitrogen and deprotonated phenolate oxygen with $\mathrm{Ni}$ (II) ion to form distorted square planer complexes. Ni(II) complexes on evaluation against Drug-Resistant Extended Spectrum $\beta$-Lactamase (ESBL), Metallo $\beta$-lactamase (MBL) producing uropathogens and some laboratory cultures exhibited promising antimicrobial activity. These compounds were also tested against Mycobacterium tuberculosis to exhibit moderate antitubercular activity.
\end{abstract}

Keywords: Schiff base; Ni(II) complexes Antitubercular activity; Antimicrobial activity; ESBL, MBL, M. tuberculosis.

(C) RASĀYAN. All rights reserved

\section{INTRODUCTION}

Schiff bases are a condensation product of a primary amine with a carbonyl compound containing azomethine or imine group. These compounds are also known as anils, imines or azomethines. ${ }^{1}$ Schiff bases play a fundamental role in the advancement of coordination chemistry as they are capable of forming a very stable metal complex with most of the transition metal ions ${ }^{2}$. For the last three decades, the coordination chemistry of Schiff base multidentate ligands with $3 \mathrm{~d}$ transitions metals has developed rapidly and is of utmost importance owing to their multi-state applications in medicinal chemistry. ${ }^{3,4}$ Metal chelates of the Schiff bases have been extensively studied for their biological activity, unusual magnetic properties, stereochemical and electronic properties, catalytic biochemical processes, and novel structural features $^{5-7}$. The presence of a functional group like $-\mathrm{SH}$ or $-\mathrm{OH}$ close to azomethine group of Schiff's base makes them excellent ligand forming a five or six membered metal chelates. ${ }^{8}$

Nickel is possibly essential trace mineral and is a key element in the active center of different enzymes in different microbial pathways such as carbon cycle involving $\mathrm{CO}$ dehydrogenase (CODH), acetyl-CoA synthase (ACS), and methyl-coenzyme M reductase (MCR). ${ }^{9}$ Nickel is used as a virulence determinant factor for the human gastric pathogen Helicobacter pylori. The pathogen has two types of nickel enzymes, $[\mathrm{NiFe}]$ hydrogenase and urease, which are essential for in vivo colonization. These nickel trafficking enzymes contribute to virulence and are probable therapeutic targets for dealing with $\mathrm{H}$. pylori infections. ${ }^{10,11}$ Nickel is found in RNA and imagined to be involved in protein function. Nickel is thought to be involved in the breakdown of glucose and in prolactin production. Though, nickel plays important roles in the biology of microorganisms and plants, the biological functions of nickel are still unclear in the human body. Most of the biological data about nickel come from animal testing, and its relevance to 
humans is still unproven. More research work is needed to reveal the biological activity of this mineral in human body. ${ }^{12}$

Urinary tract infections (UTIs) are one of the most common bacterial infections experienced in the society. ${ }^{13,14}$ Chances of a person to be infected with UTI are at-least once in a lifetime ${ }^{15}$ and the most commonly confronted gram negative bacterias are E.coli, K.pneumoniae, Citrobacter spp, P.aeruginosa and Proteus spp ${ }^{16}$. The recent surfacing of antibiotic-resistant ESBL and MBL bacterial strains have made the treatment of these common infectious diseases extremely difficult. Additionally, a high degree of resistance exhibited by these strains to other types of antibiotics adds to the problem ${ }^{17}$. The continuous rise in microbial resistance to almost all types of antibiotics is becoming a global health concern. The random and extensive use of antibiotics has made the situation more challenging. Tuberculosis (TB) is one of the top 10 causes of deaths worldwide by various strains of mycobacteria, usually M. tuberculosis [MTB]. As per the World Health Organization (WHO) statistics for 2015, out of 10.4 million global cases of TB, 1.8 million people died from the disease ${ }^{18}$. Among Indian population, about $40 \%$ might be infected with TB bacteria, with most of them having latent rather than active $\mathrm{TB}^{19}$. Due to prolonged treatment period and multidrug resistivity, novel drugs with enhanced activity against drug-resistant strains and shortened duration of therapy must be developed on priority.

\section{Materials and Methods}

\section{EXPERIMENTAL}

The entire chemicals used were of analytical grade. Purified and distilled solvents were used for synthesis and physical measurements. Molar conductivity was determined in DMF solvent $\left(10^{-3} \mathrm{M}\right)$ using ELICO Digital conductivity meter Model CM-180 at RT. The elemental analysis was done using Thermo Finnigan CHNS(O) Analyzer and nickel percentage was calculated using ARCOS, ICP-Atomic Emission Spectrometer. Chlorine percentage was estimated by Volhards method ${ }^{20}$. The FTIR spectral analysis and far IR spectral analysis was carried out using Perkin Elmer Model 1600 FTIR Spectrophotometer and Bruker made 3000 Hyperion Microscope with Vertex 80 FTIR spectrometer respectively. For electronic spectral analysis, a UV-Vis-Jasco Spectrophotometer Model V-630 was employed. The X-ray diffraction patterns of the complexes were recorded on Philips made PANalytical X-ray diffractometer. For magnetic susceptibility calculations, Gouy balance and $\mathrm{Hg}\left[\mathrm{Co}(\mathrm{SCN})_{4}\right]$ as calibrant was used. Thermogravimetric studies of the complex were done on PERKIN ELMER, diamond thermogravimetric analyzer.

\section{Antimicrobial Screening \\ Test organisms}

All the gram-negative uropathogens and laboratory cultures were obtained from neighboring hospitals and pathological laboratories located in Mumbai and studied for ESBL and MBL activity in our laboratory. ${ }^{21}$,

${ }_{22}$ Eight laboratory cultures which were non-ESBL and non-MBL (Laboratory cultures Bacillus spp, $E$. coli, S. aureus, S. aureus 6538p, Proteus vulgaris, Salmonella typhi, Corynebacterium diphtheria and Streptococcus pyogenes) and ESBL and MBL isolates were used in antimicrobial activity evaluation (Table-4).

\section{Antimicrobial susceptibility of uropathogens}

Kirby Bauer method was used to study antibiotic sensitivity profile of the pathogens ${ }^{23}$.

\section{Antibacterial Screening}

Agar well diffusion method was employed for antibacterial activity evaluation of Schiff bases and Ni(II) complexes. ${ }^{24-27}$ The final concentration of $32 \mu \mathrm{g} / \mathrm{ml}$ of synthesized compound was obtained using HPLC grade DMSO. Using Brain Heart infusion $(10 \mathrm{ml})$ the bacterial culture was inoculated and incubated at $37^{\circ} \mathrm{C}$ for one day. Further, molten Mueller and Hinton agar butt $(20 \mathrm{ml})$ was cooled to $40^{\circ} \mathrm{C}$ and seeded using test culture $(0.4 \mathrm{ml}, 0.1$ O.D. at $540 \mathrm{~nm})$. This culture was transferred to a $9 \mathrm{~cm}$ a Petri plate $(9 \mathrm{~cm}$ diameter). As the medium is settled, wells $(8 \mathrm{~mm}$ diameter) were bored in this plate. Test wells and control wells were filled with each $50 \mu \mathrm{l}$ of the test compound and DMSO respectively. These plates were 
RASĀYAN J. Chem.

Vol. 10 | No. 4 |1511-1520| October - December | 2017

incubated at $37^{\circ} \mathrm{C}$ for another one day to develop the zones of inhibition. The antimicrobial screening was repeated in three settings for each isolate and the final results were given as mean \pm Standard Deviation.

\section{Anti-tuberculosis Screening}

The antitubercular screening of all compounds was carried out against M. tuberculosis (H37Rv, ATCC No-27294) by microplate Alamar Blue assay method. The methodology is non-toxic and parallel with proportional and BACTEC radiometric method. It uses a thermally stable reagent. During incubation, 100 $\mu \mathrm{l}$ of the Middlebrook $7 \mathrm{H} 9$ broth, $200 \mu \mathrm{l}$ of sterile de-ionized water and serial dilution of compounds were mixed in all wells of sterile 96 well plate. The plate was enclosed and potted with paraffin and incubated for five days at $37^{\circ} \mathrm{C}$. The test compounds were prepared at different drug concentrations from 100 to $0.8 \mu \mathrm{g} / \mathrm{ml}$. A mixture $(25 \mu \mathrm{l})$ of Almar Blue reagent and Tween $10 \%$ and Tween $80 \%$ was freshly prepared in 1:1 ratio and added to plate wells. The plate was further incubated for another one day to develop the coloration. A blue color of well-indicated inhibition of bacterial growth, whereas pink color well considered as the growth of Mycobacterium ${ }^{28}$.

\section{Synthesis of Schiff Bases}

The Schiff bases (Fig.-1) were prepared by the condensation reaction of ethyl 2-amino-5,6-dihydro-4Hcyclopenta[b]thiophene-3-carboxylate and differently substituted aldehydes as per literature method ${ }^{29}$.

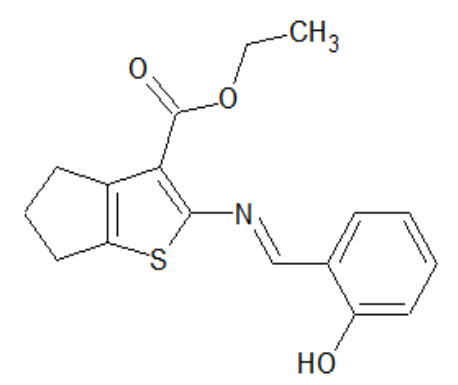

ethyl $2-\{[(E)-(2$-hydroxy phen yl) methylidene]amino $\}-5,6$ -dihydro- $4 H$-cyclopenta[ $b]$ thiophene-3-carboxylate $\left(\mathrm{HL}_{1}\right)$

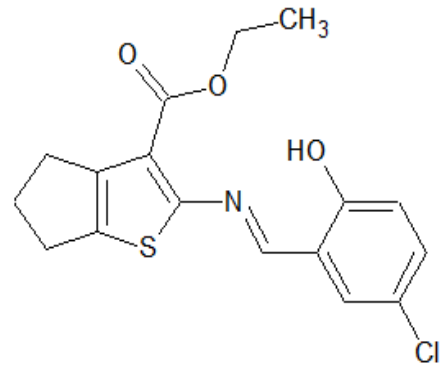

ethyl 2-\{[(E)-(5-chloro-2-hydroxypheny1)methylidene $]$ amino $\}-5,6$ -dihydro-4H-cyclopenta[b] thiophene-3-carboxylate $\left(\mathrm{HL}_{2}\right)$

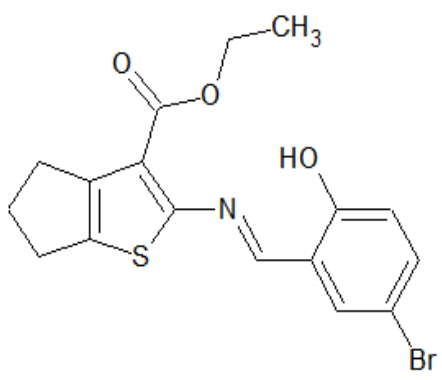

ethyl $2-\{[(E)-(5$-brom o-2-hydrox yphenyl $)$ me thylidene $]$ amino $\}-5,6$
-dihydro-4H-cyclopenta $[b]$ thi ophene- 3 -carboxylate
$\left(\mathrm{HL}_{3}\right)$

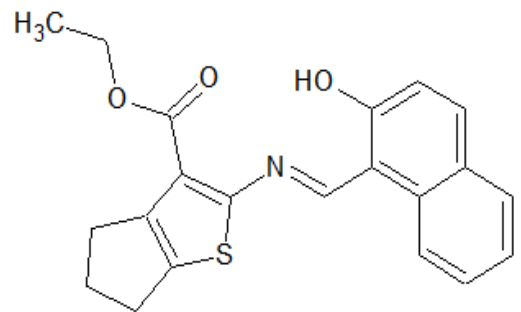

ethyl 2-\{[(E)-(2-hydroxynap htha len-1-yl)methylidene]amino $\}-5,6$ -dihydro-4H-cyclopenta[ $b]$ thiophene-3-carboxylate

$\left(\mathrm{HL}_{4}\right)$

\section{Synthesis of Metal Complexes}

Fig.-1: Schiff Base ligands

Nickel chloride $(0.01 \mathrm{~mol})$ and Schiff base $\left(\mathrm{HL}_{1}-\mathrm{HL}_{4}\right)(0.01 \mathrm{~mol})$ in ethanol were added dropwise with $\mathrm{pH}$ adjusted to 6.5 using ethanolic ammonia. The resulting mixture was refluxed on a water bath for 5-6 h. 
RASĀYAN $J$. Chem.

Vol. 10 | No. 4 |1511-1520| October - December | 2017

The product formed was filtered and washed sequentially with aqueous ethanol and ether and allowed dry in a vacuum.

\section{RESULTS AND DISCUSSION}

All the prepared Schiff base ligands and their Ni(II) complexes were nonhygroscopic and stable at RT. The complexes were mostly insoluble in organic solvents except for DMF and DMSO. Elemental analysis and molar conductance data of Nickel complexes depicted in Table-1, suggested 1:1 (metal: ligand) stoichiometry.

Table-1: Physicochemical Characteristics of Nickel complexes

\begin{tabular}{|c|c|c|c|c|c|c|c|c|c|}
\hline \multirow[b]{2}{*}{ Complex } & \multirow[b]{2}{*}{ Colour } & \multirow[b]{2}{*}{ F.W. } & \multicolumn{6}{|c|}{ Elemental analysis (\%) found (calc.) } & \multirow{2}{*}{$\begin{array}{c}\text { Molar } \\
\text { conductance } \\
\text { in DMF } \\
\left(\Omega^{-1} \mathrm{~cm}^{2} \mathrm{~mol}^{-1}\right)\end{array}$} \\
\hline & & & C & $\mathrm{H}$ & $\mathrm{N}$ & S & $\mathrm{Cl}$ & M & \\
\hline$\left[\mathrm{Ni}\left(\mathrm{L}_{1}\right) \mathrm{Cl}\right]$ & Red & 408.52 & $\begin{array}{c}49.29 \\
(49.93)\end{array}$ & $\begin{array}{c}3.87 \\
(3.91) \\
\end{array}$ & $\begin{array}{c}3.48 \\
(3.42) \\
\end{array}$ & $\begin{array}{c}7.78 \\
(7.83) \\
\end{array}$ & $\begin{array}{c}8.31 \\
(8.68) \\
\end{array}$ & $\begin{array}{c}14.75 \\
(14.37) \\
\end{array}$ & 6.10 \\
\hline$\left[\mathrm{Ni}\left(\mathrm{L}_{2}\right) \mathrm{Cl}\right]$ & Firebrick & 442.97 & $\begin{array}{c}46.27 \\
(46.05) \\
\end{array}$ & $\begin{array}{c}3.43 \\
(3.39) \\
\end{array}$ & $\begin{array}{c}3.24 \\
(3.16) \\
\end{array}$ & $\begin{array}{c}6.97 \\
(7.22) \\
\end{array}$ & $\begin{array}{c}16.25 \\
(16.01) \\
\end{array}$ & $\begin{array}{c}13.16 \\
(13.25) \\
\end{array}$ & 1.30 \\
\hline$\left[\mathrm{Ni}\left(\mathrm{L}_{3}\right) \mathrm{Cl}\right]$ & Red & 487.42 & $\begin{array}{c}41.63 \\
(41.85)\end{array}$ & $\begin{array}{c}3.12 \\
(3.08)\end{array}$ & $\begin{array}{c}2.90 \\
(2.87)\end{array}$ & $\begin{array}{c}6.34 \\
(6.57) \\
\end{array}$ & $\begin{array}{c}7.74 \\
(7.28)\end{array}$ & $\begin{array}{c}11.90 \\
(12.04)\end{array}$ & 5.80 \\
\hline$\left[\mathrm{Ni}\left(\mathrm{L}_{4}\right) \mathrm{Cl}\right]$ & Firebrick & 458.58 & $\begin{array}{c}54.42 \\
(54.95)\end{array}$ & $\begin{array}{c}3.75 \\
(3.92)\end{array}$ & $\begin{array}{c}3.11 \\
(3.05)\end{array}$ & $\begin{array}{c}6.84 \\
(6.98) \\
\end{array}$ & $\begin{array}{c}7.68 \\
(7.73)\end{array}$ & $\begin{array}{c}13.05 \\
(12.80)\end{array}$ & 5.50 \\
\hline
\end{tabular}

\section{FTIR Spectra and Molar Conductance}

The essential IR peaks of Schiff bases and nickel complexes are depicted in Table-2. Broad band appearing in the region $3000-3200 \mathrm{~cm}^{-1}$ in the IR spectra of Schiff bases was attributed to phenolic $-\mathrm{OH}$, which was missing in Nickel complexes, indicating coordination of deprotonated phenolate oxygen to the Nickel ion. This is further supported by shifting of the sharp band in the region 1307-1311 of phenolic oxygen (C-O) in free ligand to higher wave number region by $20-30 \mathrm{~cm}^{-1}$. Strong absorption bands observed in the region $1682-1708 \mathrm{~cm}^{-1}$ and at 1597-1598 are attributable to ester carbonyl (-C=O-) and azomethine $(-\mathrm{CH}=\mathrm{N}-)$ group respectively, which were shifted to lower wave numbers by $30-50 \mathrm{~cm}^{-1}$ and $20 \mathrm{~cm}^{-1}$ respectively indicating coordination by ester carbonyl oxygen and azomethine nitrogen to central $\mathrm{Ni}(\mathrm{II})$ ion. The stretching vibrations due to $v(\mathrm{C}-\mathrm{S})$ in the region $616-627 \mathrm{~cm}^{-1}$ showed no significant change, indicating the non-involvement of thiophene sulphur in coordination. The emergence of nonligand bands in the range $513-521 \mathrm{~cm}^{-1}$ and $415-422 \mathrm{~cm}^{-1}$ can be assigned to $v(\mathrm{M}-\mathrm{O})$ and $v(\mathrm{M}-\mathrm{N})$ stretching vibrations respectively. The far IR spectra of $\left[\mathrm{Ni}\left(\mathrm{L}_{2}\right) \mathrm{Cl}\right]$ complex displayed new medium intensity bands at $363 \mathrm{~cm}^{-1}$ depicted to $v(\mathrm{M}-\mathrm{Cl})$ band. Molar conductance of all metal complexes was measured in DMF $\left(10^{-3} \mathrm{M}\right)$ at room temperature. Results revealed small molar conductance values indicating the non-electrolytic character of nickel complexes. The results are given in Table-1.

\section{Magnetic Moments and Electronic Spectra}

The UV-Visible spectra of $\mathrm{Ni}(\mathrm{II})$ complexes show two absorption band in the range $20000-22000 \mathrm{~cm}^{-1}$ and 24000-26000 $\mathrm{cm}^{-1}$ (Table-3 and Fig.-2) assignable to ${ }^{1} \mathrm{~A}_{1 \mathrm{~g}} \rightarrow{ }^{1} \mathrm{~A}_{2 \mathrm{~g}}$ and ${ }^{1} \mathrm{~A}_{1 \mathrm{~g}} \rightarrow{ }^{1} \mathrm{~B}_{1 \mathrm{~g}}$ transitions respectively indicating square planer geometry ${ }^{30}$. Due to large crystal field splitting in square planer complexes, the energy separation between the $d_{x 2-y 2}$ and $d_{x y}$ orbital is greater than $10000 \mathrm{~cm}^{-1}$, hence no band was observed below $10000 \mathrm{~cm}^{-1,31}$ All complexes are diamagnetic, which further confirms square planer geometry of the metal complexes. ${ }^{32,33}$

Table-2: Important IR spectral bands $\left(\mathrm{cm}^{-1}\right)$

\begin{tabular}{c|c|c|c|c|c|c|c|c}
\hline Compound & $\mathrm{HL}_{1}$ & $\mathrm{HL}_{2}$ & $\mathrm{HL}_{3}$ & $\mathrm{HL}_{4}$ & {$\left[\mathrm{Ni}\left(\mathrm{L}_{1}\right) \mathrm{Cl}\right]$} & {$\left[\mathrm{Ni}\left(\mathrm{L}_{2}\right) \mathrm{Cl}\right]$} & {$\left[\mathrm{Ni}_{2}\left(\mathrm{~L}_{3}\right) \mathrm{Cl}\right]$} & {$\left[\mathrm{Ni}\left(\mathrm{L}_{4}\right) \mathrm{Cl}\right]$} \\
\hline \multirow{2}{*}{$\mathrm{v}(\mathrm{O}-\mathrm{H})$} & $3200-$ & $3200-$ & $3200-$ & $3200-$ & - & - & - & - \\
\hline
\end{tabular}


RASĀYAN $J$. Chem.

Vol. 10 | No. 4 |1511-1520| October - December | 2017

\begin{tabular}{c|c|c|c|c|c|c|c|c}
\hline$v(\mathrm{C}=\mathrm{O})$ & 1682 & 1704 & 1708 & 1704 & 1650 & 1650 & 1652 & 1664 \\
\hline$v(\mathrm{C}=\mathrm{N})$ & 1597 & 1598 & 1598 & 1598 & 1578 & 1578 & 1579 & 1579 \\
\hline$v(\mathrm{C}-\mathrm{O})$ & 1310 & 1311 & 1311 & 1307 & 1329 & 1330 & 1343 & 1330 \\
\hline$v(\mathrm{C}-\mathrm{S})$ & 616 & 619 & 626 & 617 & 620 & 622 & 627 & 618 \\
\hline$v(\mathrm{M} \leftarrow \mathrm{O})$ & - & - & - & - & 520 & 519 & 521 & 513 \\
\hline$v(\mathrm{M} \leftarrow \mathrm{N})$ & - & - & - & - & 422 & 415 & 415 & 415 \\
\hline$v(\mathrm{M} \leftarrow \mathrm{Cl})$ & - & - & - & - & - & 363 & - & - \\
\hline
\end{tabular}

Table-3: Electronic spectral bands and Magnetic moment

\begin{tabular}{|c|c|c|c|}
\hline Complex & $\begin{array}{c}\text { Absorption bands } \\
\left(\mathrm{cm}^{-1}\right)\end{array}$ & $\begin{array}{c}\text { Tentative } \\
\text { assignment }\end{array}$ & $\begin{array}{c}\text { Magnetic moment } \\
\text { (BM) }\end{array}$ \\
\hline \multirow{2}{*}[\mathrm{Ni}(\mathrm{L}_{1})\mathrm{Cl}]{} & 20000 & ${ }^{1} \mathrm{~A}_{1 \mathrm{~g}} \rightarrow{ }^{1} \mathrm{~A}_{2 \mathrm{~g}}$ & \multirow{2}{*}{$\mathrm{D}$} \\
\hline & 24390 & ${ }^{1} \mathrm{~A}_{1 \mathrm{~g}} \rightarrow{ }^{1} \mathrm{~B}_{1 \mathrm{~g}}$ & \\
\hline \multirow{2}{*}[\mathrm{Ni}(\mathrm{L}_{2})\mathrm{Cl}]{} & 21050 & ${ }^{1} \mathrm{~A}_{1 \mathrm{~g}} \rightarrow{ }^{1} \mathrm{~A}_{2 \mathrm{~g}}$ & \multirow{2}{*}{ D } \\
\hline & 24449 & ${ }^{1} \mathrm{~A}_{1 \mathrm{~g}} \rightarrow{ }^{1} \mathrm{~B}_{1 \mathrm{~g}}$ & \\
\hline \multirow{2}{*}[\mathrm{Ni}(\mathrm{L}_{3})\mathrm{Cl}]{} & 20200 & ${ }^{1} \mathrm{~A}_{1 \mathrm{~g}} \rightarrow{ }^{1} \mathrm{~A}_{2 \mathrm{~g}}$ & \multirow{2}{*}{$\mathrm{D}$} \\
\hline & 24691 & ${ }^{1} \mathrm{~A}_{1 \mathrm{~g}} \rightarrow{ }^{1} \mathrm{~B}_{1 \mathrm{~g}}$ & \\
\hline \multirow{2}{*}[\mathrm{Ni}(\mathrm{L}_{4})\mathrm{Cl}]{} & 20000 & ${ }^{1} \mathrm{~A}_{1 \mathrm{~g}} \rightarrow{ }^{1} \mathrm{~A}_{2 \mathrm{~g}}$ & \multirow{2}{*}{ D } \\
\hline & 25641 & ${ }^{1} \mathrm{~A}_{1 \mathrm{~g}} \rightarrow{ }^{1} \mathrm{~B}_{1 \mathrm{~g}}$ & \\
\hline
\end{tabular}

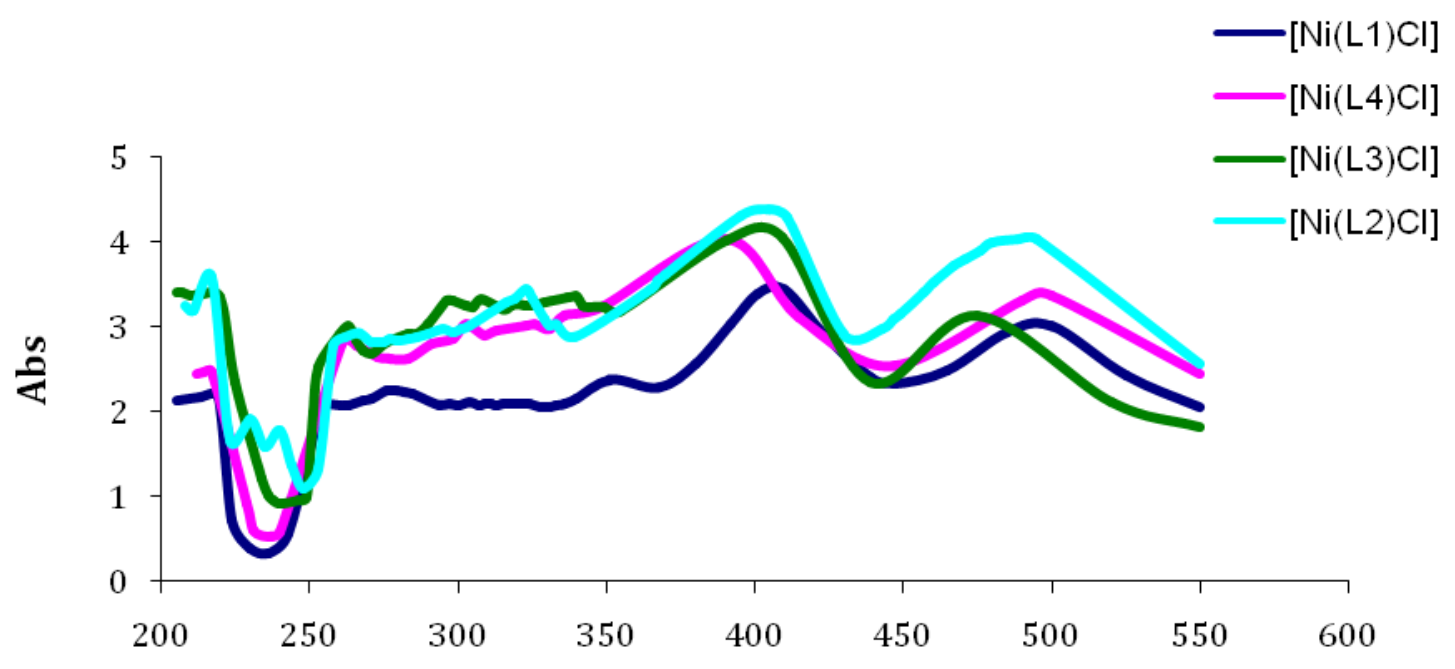

Wavelength (nm)

\section{Thermal Analysis}

Fig.-2: Electronic spectra of Ni(II) complexes

The thermogram of the $\left[\mathrm{Ni}\left(\mathrm{L}_{2}\right) \mathrm{Cl}\right]$ metal complexes under nitrogen atmosphere shown in Fig.-3, revealed two-stage decomposition process with insignificant weight loss up to $180^{\circ} \mathrm{C}$. Hence, the possibility of the water coordination in the complex is ruled out. The first step, TG loss was observed in the temperature range $180-350^{\circ} \mathrm{C}$ with the estimated mass loss of $44.08 \%$ (calc. $44.13 \%$ ) corresponding to an aminothiophene moiety. Second step TG loss was found in the temperature range $400-680^{\circ} \mathrm{C}$ with estimated mass loss of $38.06 \%$ (calc. $38.71 \%$ ) accounting for the mass loss of salicylaldehyde moiety. 
RASĀYAN J. Chem.

Vol. 10 | No. 4 |1511-1520| October - December | 2017

Above $700^{\circ} \mathrm{C}$, a remaining residue with the mass of $16.86 \%$ (calc. $17.16 \%$ ) was left which was weight equivalent to nickel oxide.

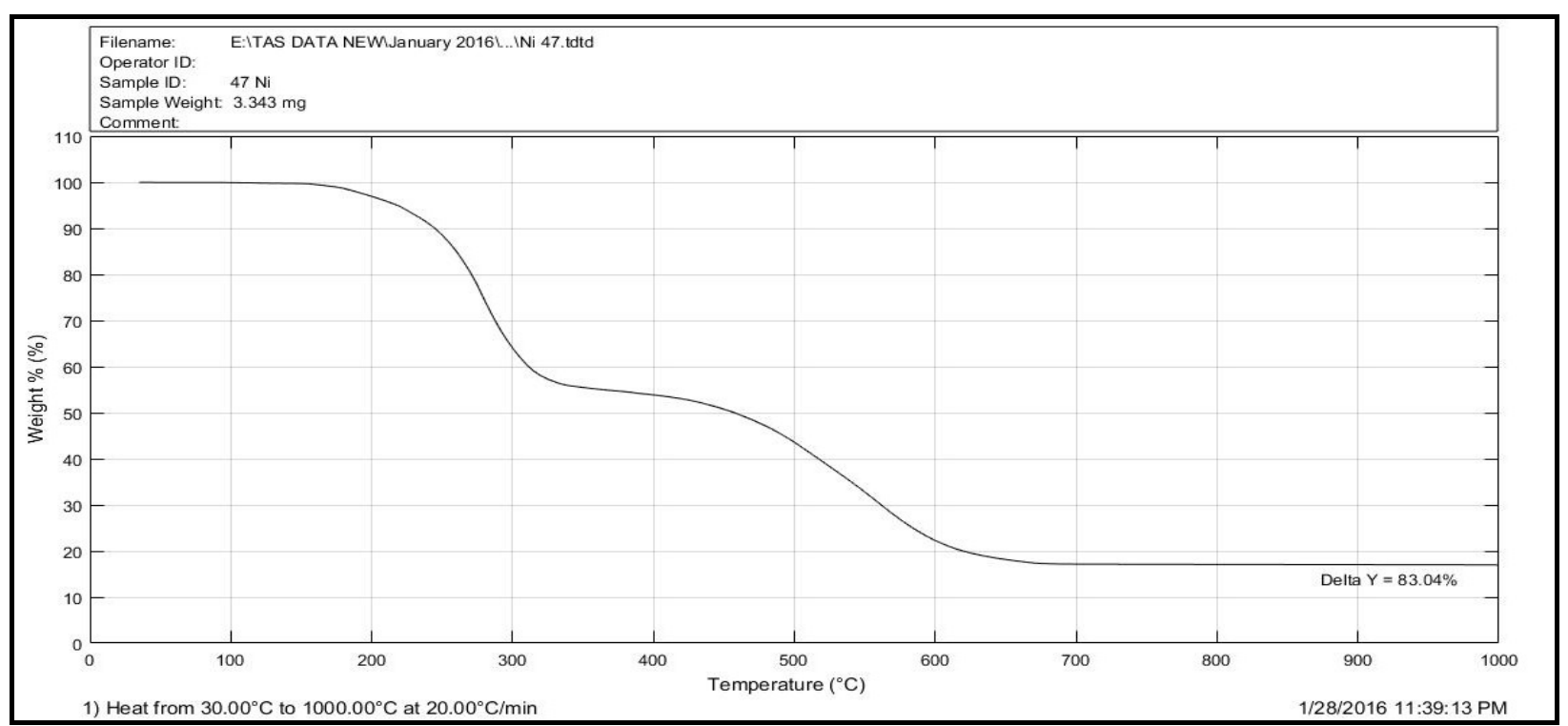

Fig.-3: Thermogram of $\left[\mathrm{Ni}\left(\mathrm{L}_{2}\right) \mathrm{Cl}\right]$ complex

\section{X-ray Diffraction Analysis}

The powder X-Ray diffractogram $(\mathrm{XRD})$ of the $\left[\mathrm{Ni}\left(\mathrm{L}_{1}\right) \mathrm{Cl}\right]$ complex was recorded using $\mathrm{CuK} \alpha$ radiation source on PANanalytical X-ray diffractometer at the wavelength of $1.5406 \AA$. The powder sample was scanned in the $2 \theta$ range $10^{\circ}$ to $90^{\circ}$. The crystal structure of this compound was refined by a least-squares method on the basis of observed reflections using Rietveld refinement technique. ${ }^{34}$ Diffractogram indicating amorphous nature of the complex is depicted in Figure 4. The complex showed maximum reflection at a $2 \theta=22.6952^{\circ}$ corresponding interplanar distance of $d=3.9149 \AA$. The unit cell lattice parameters observed were, $a=8.0830 \AA$, $b=9.2990 \AA \hat{,}, c=10.9220 \AA \hat{\alpha}, \alpha=67.735^{\circ}, \beta=82.665^{\circ}, \gamma=$ $85.860^{\circ}, Z=1, V=753.26 \AA^{3}$ and calculated density $=4.338 \mathrm{~g} / \mathrm{cm}^{3}$. This compound crystallizes in the triclinic space group $P-1 .{ }^{35}$

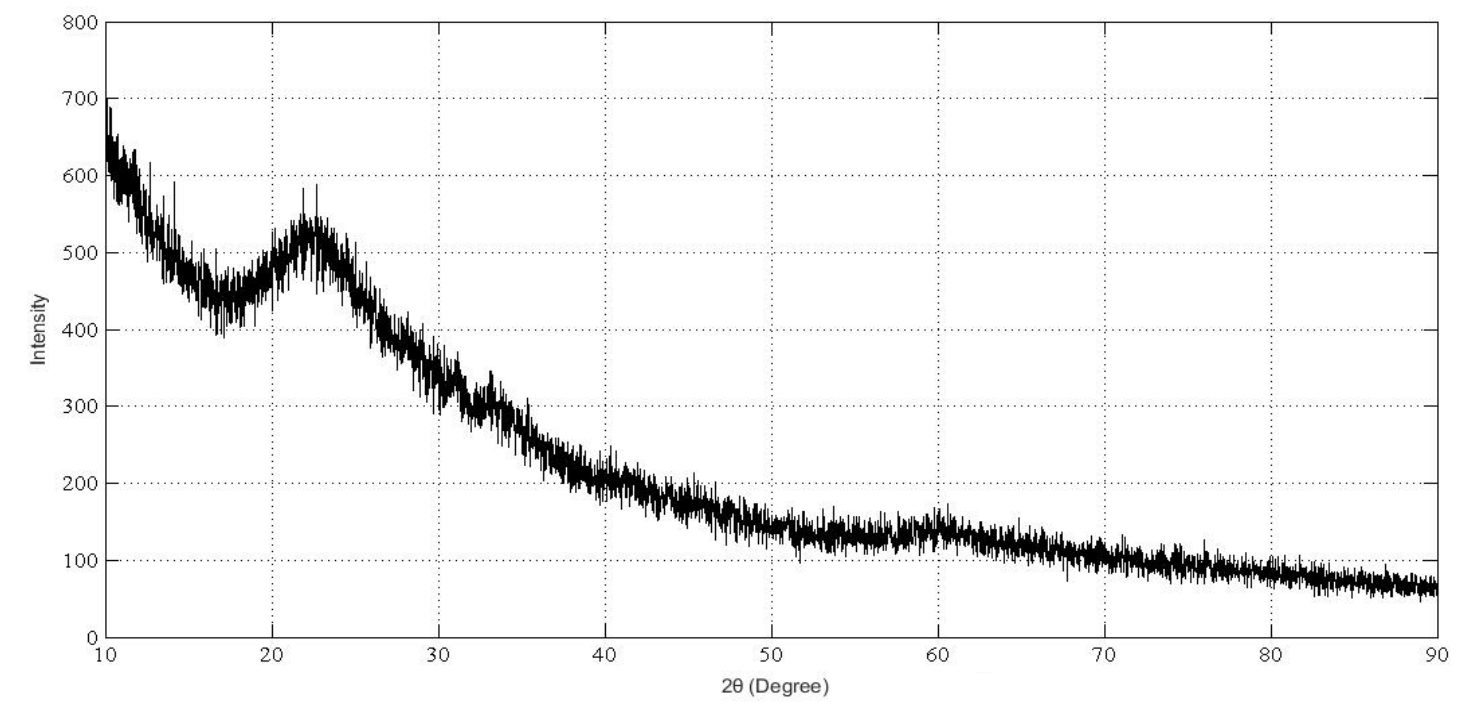

Fig.-4: X-ray diffractogram of $\left[\mathrm{Ni}\left(\mathrm{L}_{1}\right) \mathrm{Cl}\right]$ complex 
RASĀYAN J. Chem.

Vol. 10 | No. 4 |1511-1520| October - December | 2017

The square planer structure of nickel complexes (Fig.-5) can be proposed with ligand coordinating through $\mathrm{O}, \mathrm{N}$ and $\mathrm{O}$ atom to nickel ion based on different spectroscopic and physicochemical evaluations.

\section{Biological Activity \\ Antimicrobial Activity}

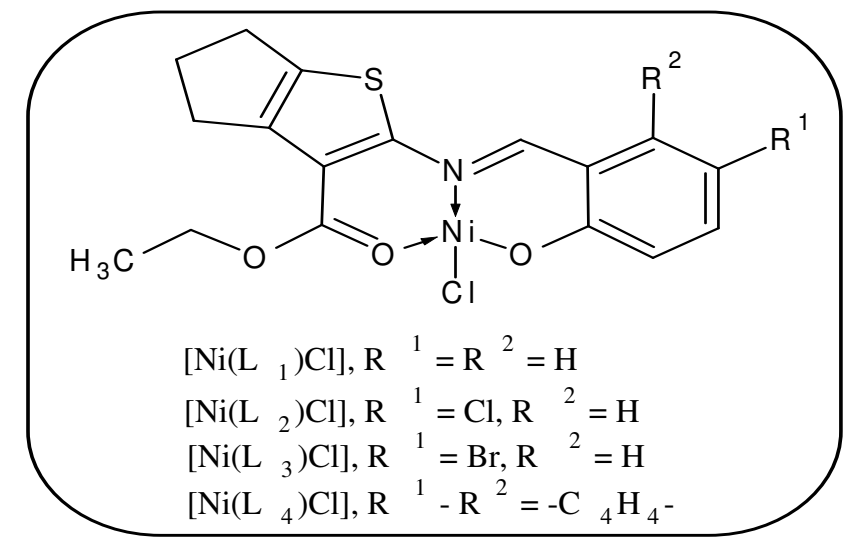

Fig.-5: Proposed structure of Nickel complex

Antimicrobial activity of all synthesized compounds was evaluated by Kirby Bauer method. Multiple Drug Resistant ESBL and MBL microbial strains along with drug-sensitive laboratory isolates were used in the current study (Table-4). The antimicrobial activity report of the Schiff bases and nickel complexes is presented in Table-5. DMSO as a solvent showed no zone of inhibition. All the Nickel complexes exhibited significant zones of inhibition against all the test microbial strains. Schiff bases showed no zone of inhibition against Citro-2, Pseudo and Pro-7 ESBL strains and isolate-607, isolate-618 and isolate-220 (except $\mathrm{HL}_{2} \& \mathrm{HL}_{3}$ ) MBL strains, while their respective nickel complexes showed a significant zone of inhibition on complex formation. Nickel complexes displayed improved microbial activity against Ec-10, Kp-7 and isolate-135 as compared to parent Schiff bases. While similar antimicrobial activity profile was observed against isolate-85 and isolate-220 (except $\mathrm{HL}_{1} \& \mathrm{HL}_{4}$ ) MBL producers. No considerable difference in zones of inhibition was observed between antibiotic resistant (ESBL and MBL producers) and antibiotic sensitive (i.e. laboratory) organisms. Nickel complexes showed considerable antimicrobial activity with zones of inhibition $10-16 \mathrm{~mm}$ against all the laboratory isolates used in the study. $\left[\mathrm{Ni}\left(\mathrm{L}_{3}\right) \mathrm{Cl}\right]$ complex was found to be the most active compound against all microorganism.

The improved antimicrobial activity of nickel complexes compared to parent Schiff bases can be ascribed to the theory of chelation. Donor atoms present in the ligands partially share positive charge on the metal atom leading to $\pi$-electron delocalization which increases the lipophilicity of metal complex increasing a permeability within the lipid layer of the microorganisms. This facilitates deep penetration of the metal complex in the lipid layer and blocks metal coordination sites on microbial enzymes ${ }^{36}$. Similar to our findings, latest studies revealed antimicrobial activity profile of Nickel complexes against bacterial and fungal cultures which did not show any considerable difference between zones of inhibition of bacterial or fungal cultures $(9-30 \mathrm{~mm}) .^{37,38}$

Table-4: Microbial Cultures

\begin{tabular}{c|c|c}
\hline Culture Type & Cultures used & Full form \\
\hline \multirow{4}{*}{ ESBL } & Citro-2 & Citrobacterdiversus \\
\cline { 2 - 3 } & Ec- 10 & Escherichia coli- 10 \\
\cline { 2 - 3 } & Pseudo & Pseudomonas aeruginosa \\
\cline { 2 - 3 } & Kp-7 & Klebsiella pneumoniae- 7 \\
\cline { 2 - 3 } & Pro- 7 & Proteus mirabilis- 7 \\
\hline \multirow{4}{*}{ MBL } & 85 & Pseudomonas aeruginosa \\
\cline { 2 - 3 } & 135 & Citrobacteramalonaticus \\
\cline { 2 - 3 } & 220 & Escherichia coli \\
\cline { 2 - 3 } & 607 & Proteus mirabilis \\
\hline
\end{tabular}


RASĀYAN J. Chem.

Vol. 10 | No. 4 |1511-1520| October - December | 2017

\begin{tabular}{l|c|c}
\hline & 618 & Klebsiella pneumoniae \\
\hline \multirow{4}{*}{ Laboratory cultures } & Bacillus & Bacillus subtilis \\
\cline { 2 - 3 } & E. coli & Escherichia coli \\
\cline { 2 - 3 } & S. aureus & Staphylococcus aureus \\
\cline { 2 - 3 } & S. aureus 6538p & Staphylococcus aureus $6538 \mathrm{p}$ \\
\cline { 2 - 3 } & P. vulgaris & Proteus vulgaris \\
\cline { 2 - 3 } & S. typhi & Salmonella typhimurium \\
\cline { 2 - 3 } & C. diphtheriae & Corynebacterium diphtheriae \\
\cline { 2 - 3 } & Streptococcus & Streptococcus pyogenes \\
\cline { 2 - 3 }
\end{tabular}

Table-5: Antibacterial activity of Nickel complexes

\begin{tabular}{|c|c|c|c|c|c|c|c|c|c|c|}
\hline \multirow[b]{2}{*}{ S. No. } & \multirow{2}{*}{$\begin{array}{l}\text { Cultures code } \\
\text { name }\end{array}$} & \multicolumn{9}{|c|}{ Zone of inhibition in $\mathrm{mm}$} \\
\hline & & $\mathrm{HL}_{1}$ & {$\left[\mathrm{Ni}\left(\mathrm{L}_{1}\right) \mathrm{Cl}\right]$} & $\mathrm{HL}_{2}$ & {$\left[\mathrm{Ni}\left(\mathrm{L}_{2}\right) \mathrm{Cl}\right]$} & $\mathrm{HL}_{3}$ & {$\left[\mathrm{Ni}\left(\mathrm{L}_{3}\right) \mathrm{Cl}\right]$} & $\mathrm{HL}_{4}$ & {$\left[\mathrm{Ni}\left(\mathrm{L}_{4}\right) \mathrm{Cl}\right]$} & $\begin{array}{c}\text { DMSO } \\
\text { (solvent) }\end{array}$ \\
\hline \multicolumn{11}{|c|}{ ESBL PRODUCERS } \\
\hline 1 & Citro-2 & 0 & 13 & 0 & 13 & 0 & 13 & 0 & 10 & 0 \\
\hline 2 & Ec- 10 & 11 & 13 & 11 & 13 & 10 & 14 & 10 & 12 & 0 \\
\hline 3 & $\mathrm{Kp}$ & 0 & 13 & 0 & 15 & 0 & 18 & 0 & 22 & 0 \\
\hline 4 & Kp-7 & 11 & 11 & 12 & 13 & 10 & 13 & 12 & 12 & 0 \\
\hline 5 & Pro- 7 & 0 & 13 & 0 & 11 & 0 & 16 & 0 & 12 & 0 \\
\hline \multicolumn{11}{|c|}{ MBL PRODUCERS } \\
\hline 6 & 85 & 12 & 14 & 15 & 12 & 15 & 15 & 15 & 14 & 0 \\
\hline 7 & 135 & 16 & 17 & 17 & 20 & 15 & 18 & 15 & 16 & 0 \\
\hline 8 & 220 & 0 & 19 & 11 & 11 & 11 & 15 & 0 & 10 & 0 \\
\hline 9 & 607 & 0 & 10 & 0 & 12 & 0 & 11 & 0 & 10 & 0 \\
\hline 10 & 618 & 0 & 12 & 0 & 10 & 10 & 12 & 0 & 11 & 0 \\
\hline \multicolumn{11}{|c|}{ LABORATORY ISOLATES } \\
\hline 11 & Bacillus spp & - & 15 & - & 10 & - & 12 & - & 11 & 0 \\
\hline 12 & E. coli & - & 11 & - & 13 & - & 15 & - & 10 & 0 \\
\hline 13 & S. aureus & - & 10 & - & 9 & - & 15 & - & 10 & 0 \\
\hline 14 & S. aureus $6538 p$ & - & 13 & - & 13 & - & 14 & - & 13 & 0 \\
\hline 15 & Proteus. vulgaris & - & 13 & - & 13 & - & 15 & - & 12 & 0 \\
\hline 16 & Salmonella typhi & - & 11 & - & 13 & - & 16 & - & 10 & 0 \\
\hline 17 & $\begin{array}{c}\text { Corynebacterium. } \\
\text { diphtheriae }\end{array}$ & - & 13 & - & 12 & - & 16 & - & 11 & 0 \\
\hline 18 & $\begin{array}{c}\text { Streptococcus } \\
\text { pyogenes }\end{array}$ & - & 15 & - & 14 & - & 15 & - & 12 & 0 \\
\hline
\end{tabular}

\section{Antitubercular Activity}

All synthesized compounds exhibited potency to inhibit the growth of replicating $M$. tuberculosis. Pyrazinamide, Ciprofloxacin, and Streptomycin were used as reference drugs to compare the antitubercular activity. Schiff bases and nickel complexes exhibited moderate antitubercular activity, which may be due to the presence of active pharmacophore present in the molecular structure, such as a heterocyclic ring with thiophene moiety, azomethine group and substituted hydroxyl aldehydes. All compounds displayed MIC at a concentration of $25 \mu \mathrm{g} / \mathrm{mL}$ (Table-6). There is no effective change observed in the antitubercular activity of ligands on chelation indicating no involvement of $\mathrm{Ni}$ ion in the inhibition of $M$. tuberculosis. Thus, biological activity cannot be only linked to the presence of metal ion $^{29}$.

\section{CONCLUSION}

Series of Ni(II) complexes were synthesized from Schiff bases and characterized by various analytical and spectral methods. Based on the spectroscopic evaluation, TG analysis and physicochemical data distorted square planer geometry with 1:1 metal: ligand stoichiometry was allocated to the Nickel 
RASĀYAN $J$. Chem.

Vol. 10 | No. 4 |1511-1520| October - December | 2017

complexes. All the Nickel complexes have shown promising antimicrobial activity and moderate antitubercular activity. This study may provide a stepping stone for the further development of more potent Schiff bases and nickel complexes for biological applications.

Table-6: Antitubercular Activity of Nickel Complexes

\begin{tabular}{c|c|c|c|c|c|c|c|c}
\hline \multirow{2}{*}{ Test compound } & \multicolumn{7}{|c}{$\mathrm{MIC}(\mu \mathrm{g} / \mathrm{ml})$} \\
\cline { 2 - 9 } & 100 & 50 & 25 & 12.5 & 6.25 & 3.12 & 1.60 & 0.80 \\
\hline $\mathrm{HL}_{1}$ & $\mathrm{~S}$ & $\mathrm{~S}$ & $\mathrm{~S}$ & $\mathrm{R}$ & $\mathrm{R}$ & $\mathrm{R}$ & $\mathrm{R}$ & $\mathrm{R}$ \\
\hline $\mathrm{HL}_{2}$ & $\mathrm{~S}$ & $\mathrm{~S}$ & $\mathrm{~S}$ & $\mathrm{R}$ & $\mathrm{R}$ & $\mathrm{R}$ & $\mathrm{R}$ & $\mathrm{R}$ \\
\hline $\mathrm{HL}_{3}$ & $\mathrm{~S}$ & $\mathrm{~S}$ & $\mathrm{~S}$ & $\mathrm{R}$ & $\mathrm{R}$ & $\mathrm{R}$ & $\mathrm{R}$ & $\mathrm{R}$ \\
\hline $\mathrm{HL}_{4}$ & $\mathrm{~S}$ & $\mathrm{~S}$ & $\mathrm{~S}$ & $\mathrm{R}$ & $\mathrm{R}$ & $\mathrm{R}$ & $\mathrm{R}$ & $\mathrm{R}$ \\
\hline$\left[\mathrm{Ni}\left(\mathrm{L}_{1}\right) \mathrm{Cl}\right]$ & $\mathrm{S}$ & $\mathrm{S}$ & $\mathrm{S}$ & $\mathrm{R}$ & $\mathrm{R}$ & $\mathrm{R}$ & $\mathrm{R}$ & $\mathrm{R}$ \\
\hline$\left[\mathrm{Ni}\left(\mathrm{L}_{2}\right) \mathrm{Cl}\right]$ & $\mathrm{S}$ & $\mathrm{S}$ & $\mathrm{S}$ & $\mathrm{R}$ & $\mathrm{R}$ & $\mathrm{R}$ & $\mathrm{R}$ & $\mathrm{R}$ \\
\hline$\left[\mathrm{Ni}\left(\mathrm{L}_{3}\right) \mathrm{Cl}\right]$ & $\mathrm{S}$ & $\mathrm{S}$ & $\mathrm{S}$ & $\mathrm{R}$ & $\mathrm{R}$ & $\mathrm{R}$ & $\mathrm{R}$ & $\mathrm{R}$ \\
\hline$\left[\mathrm{Ni}\left(\mathrm{L}_{4}\right) \mathrm{Cl}\right]$ & $\mathrm{S}$ & $\mathrm{S}$ & $\mathrm{S}$ & $\mathrm{R}$ & $\mathrm{R}$ & $\mathrm{R}$ & $\mathrm{R}$ & $\mathrm{R}$ \\
\hline Streptomycin & $\mathrm{S}$ & $\mathrm{S}$ & $\mathrm{S}$ & $\mathrm{S}$ & $\mathrm{S}$ & $\mathrm{R}$ & $\mathrm{R}$ & $\mathrm{R}$ \\
\hline Pyrazinamide* & $\mathrm{S}$ & $\mathrm{S}$ & $\mathrm{S}$ & $\mathrm{S}$ & $\mathrm{S}$ & $\mathrm{S}$ & $\mathrm{R}$ & $\mathrm{R}$ \\
\hline Ciprofloxacin $^{*}$ & $\mathrm{~S}$ & $\mathrm{~S}$ & $\mathrm{~S}$ & $\mathrm{~S}$ & $\mathrm{~S}$ & $\mathrm{~S}$ & $\mathrm{R}$ & $\mathrm{R}$ \\
\hline
\end{tabular}

*Standard, S - Sensitive, R - Resistant

\section{ACKNOWLEDGEMENT}

The authors wish to thank the Wilson College, Mumbai, for providing the necessary research facilities. The authors thank Dr. Kishore Bhat for providing antitubercular activity. The authors acknowledge IIT SAIF, Bombay, for analytical and spectral data. We are also thankful to Dr. Mustapha Mandewale, Dr. Paresh More and Dr. Vijay Veer for Spectral analysis.

\section{REFERENCES}

1. A.B. Cohen, Biochimica et Biophysica Acta (BBA)-Enzymology, 391(1), 193(1975).

2. K. Brodowska and E. Chruscinska, CHEMIK, 68(2),129(2014).

3. P.R. Reddy, S.K. Mohan, R.M. Raju, P. Ettaiah, Ind. J. Chem., 45A, 2381(2006).

4. M.K. Biyata, N. Fehmi, R.V. Singh, Ind. J. Chem., 45A, 1999(2006).

5. $\quad$ N. Raman and J.D. Raja, Ind. J. Chem., 46A, 1611(2007).

6. N. Bharti, M.R. Maurya, F. Naqvi, A. Azam, Bioinorg. Med. Chem. Lett., 10(20), 2243(2000).

7. G.A. Chukhadzhri, E.L. Sarkisyan, T.S. Elbakyan, Koordinats Khim., 2, 965(1976).

8. N. Mishra, K. Poonia, D. Kumar, IJOART, 2(8), 52(2013).

9. M. Krüger, 2011, Nickel Biology, in Encyclopedia of Geobiology, Springer Netherlands, pp. 684685.

10. H. De Reuse, D. Vinella, C. Cavazza, Frontiers in cellular and infection microbiology, 3, (2013). DOI: $10.3389 /$ fcimb.2013.00094

11. P. Chellan and P.J. Sadler, Phil. Trans. R. Soc., A 373.2037, 20140182(2015). DOI: 10.1098/rsta.2014.0182

12. E.M. Haas, Minerals: Nickel, Staying Healthy with Nutrition ISBN: 1587611791 http://www.healthy.net/Health/Article/Nickel/2082

13. K.G. Naber, G. Schito, H. Botto, J. Palou, T. Mazzei, European urology, 54.5, 1164(2008).

14. A. Ronald, Am. J. Med., 113(1), 14(2002).

15. S. Saint, C.P. Kowalski, S.R. Kaufman, T.P. Hofer, C.A. Kauffman, R.N. Olmsted, J. Forman, J. Banaszak-Holl, L. Damschroder, S.L. Krein, Clinical Infectious Diseases, 46(2), 243(2008).

16. A. Singhal, R. Sharma, M. Jain, L. Vyas, Ann. Med. Health. Sci. Res., 4(1), 51(2014).

17. D. Sirot, JAC, 36A, 19(1995).

18. World Health Organization, Tuberculosis Fact sheet $\mathrm{N}^{\circ} 104$, http://www.who.int/mediacentre/factsheets/fs104/en/ 2016 
19. TB India 2016, Revised National TB control Programme Annual Status Report, New Delhi. http://tbcindia.nic.in/showfile.php?lid=3180 2016

20. D.A. Skoog, D.M. West, F.J. Holler, S. Crouch, 2013, Fundamentals of analytical chemistry, Nelson Education.

21. K. Aruna and T. Mobashshera, EXCLI J., 11, 363(2012).

22. T. Mobashshera and K. Aruna, Br. Microbiol. Res. J., 5(4), 368(2015).

23. K. Aruna, M. Tariq, S. Bootwala, G. More, IJPRBS, 3(5), 222(2014).

24. S.S. Patil and M.M Shaikh, Acta Pol. Pharm., 69, 679(2012).

25. N.P. Ndahi and Y.P. Nasir, IJPSR, 3, 5116(2012).

26. K. Jamil, M. Bakhtiar, A.R. Khan, F. Rubina, R. Rehana, R. Wajid, M. Qaisar, A.F. Khan, A.K. Khan, M. Danish, M. Awais, Afr. J. Pure Appl. Chem., 3(4), 60(2009).

27. K. Rajasekar and T. Ramachandramoorthy, Int. J. Pharm. Bio. Sci., 4(2), 271(2013).

28. M.C. Lourenço, M.V. de Souza, A.C. Pinheiro, M.D.L. Ferreira, R.S. Gonçalves, T.C.M. Nogueira, M.A. Peralta, Arkivoc, 15, 181(2007).

29. G. More, D. Raut, K. Aruna, S. Bootwala, J. Saudi Chem. Soc., 2017. DOI: https://doi.org/10.1016/j.jscs.2017.05.002

30. D.C. Sawant and R.G. Deshmukh, J. Chem. Pharm. Res., 3(6), 464(2011).

31. R.K. Ray, 2011, Electronic Spectra of Transition Metal Complexes, New Central Book Agency (P) Ltd, Kolkatta, pp.387.

32. L. Sacconi, P. Nannelli, U. Campigli, Inorg. Chem., 4(6), 818(1965).

33. S.S. Konstantinović, B.C. Radovanović, Ž. Cakić, V.M. Vasić, J. Serb. Chem. Soc., 68(8-9), 641(2003).

34. H.M. Rietveld, Acta Cryst., 22(1), 151(1967).

35. X. Li, R. Cao, Z. Guo, J. Lü, Chem. Coтmu., 18, 1938(2006).

36. G.D. Bajju, P. Sharma, A. Kapahi, M. Bhagat, S. Kundan, D. Gupta, J. Inorg. Chem., 2013. DOI: http://dx.doi.org/10.1155/2013/982965

37. T.P. Popova, R.I. Alexandrova, R. Tudose, E.M. Mosoarca, O. Costisor, BULG. J. AGRIC. SCI., 18(3), 446(2012).

38. M. Rajasekar, S. Sreedaran, R. Prabu, V. Narayanan, R. Jegadeesh, N. Raaman, A. Kalilur Rahiman, J. Coord. Chem., 63(1), 136(2010).

[RJC-1951/2017] 